\title{
Julita Gamoń
}

Uniwersytet Łódzki

\section{Semantyka czerwieni w „Pożegnaniu jesieni” Stanisława Ignacego Witkiewicza ${ }^{1}$}

Materiał dotyczący barw jest mało różnorodny, wyłączając barwę czerwoną, która $w$ powieści Witkacego wysuwa się na plan pierwszy. Ilościowa przewaga tego koloru związana jest zapewne z jego konotacjami. Autor, słowami narratora wspomina o „manii czerwoności”, towarzyszącej jego bohaterom. Choć sam w przedmowie do Pożegnania jesieni pisze, iż „traktuje tę kwestię trochę humorystycznie i fantastycznie", warto sprawdzić, jaki efekt dzięki temu uzyskał.

W pracy chcę zbadać pole semantyczne czerwieni, zwracając uwagę na funkcje, jakie pełni $w$ powieści, jej przykłady $w$ tekście oraz nazwy niepodstawowe koloru czerwonego. Posługuję się metodą badawczą, opartą się na założeniach metodologicznych Ryszarda Tokarskiego, za którym do pracy nad badaniem pola semantycznego czerwieni włączam nazwę barwy różowy, definiując go, za Tokarskim, jako nieintensywny czerwony [Tokarski 2004: 157] oraz leksem rudy ${ }^{2}$, zawierający $w$ powieści konotacje z czerwienią.

1 Artykuł stanowi część pracy magisterskiej „Językowy obraz Heli Bertz w Pożegnaniu jesieni Stanisława Ignacego Witkiewicza", pisanej pod kierunkiem prof. nadzw. dr. hab. Zdzisławy Staszewskiej.

2 Zbigniew Libera przypomina, iż „pierwotnie barwę zzerwoną $w$ językach słowiańskich oznaczał rudy. Został on wyparty przez czerwony, w językach północnych i południowych Słowian (u Słowian wschodnich jego miejsca zajął krasnyj) i zepchnięty do roli nazwy określającej maść zwierząt domowych, kolor włosów i skóry człowieka. Nasz pomarańczowy, czerwony, karminowy oraz od- 
Według Tokarskiego czerwień jest barwą najdoskonalszą, od wieków utożsamianą ze sztuką magiczną (m.in. czerwone czepce czy korale mające odpędzać uroki). W Europie, do końca średniowiecza czerwień była kolorem żałoby, a posypywane czerwonym barwnikiem przedmioty miały zapewnić zmarłemu siły w zaświatach. Czerwień zwiększa ciśnienie krwi, zdolność reakcji, powoduje wydzielanie adrenaliny i wzrost aktywności organizmu [Tokarski 2004: 78-79], wpływając na samopoczucie człowieka.

Symbolika czerwieni jest dość zbieżna, zarówno w językoznawczych, jak i kulturowych ujęciach, konotując skojarzenia z ogniem i krwią. Językoznawstwo współczesne nawiązuje do teorii prototypów, odwołujących się do podstawowych doznań ludzkich: prototyp czerwieni stanowi świeża, jasna krew oraz płonący ogień [Tokarski 2004: 80-81].

Skojarzenia z pierwszym wzorcem prototypowym wykazują „krwawe usta” $(23,153,181)$ Heli, eksponowane w scenach zbliżeń kochanków. Co istotne, barwa ta nie odnosi się do innych bohaterów powieści, ich usta mają kolor czerwony.

Jak zauważa Marek Kurkiewicz:

Naturalnie pojawienie się $w$ scenach miłosnych motywu krwi nie zawsze prowokowało perwersje. Najczęściej owa krwistość jest sygnalizowana subtelnie, współbudując czasem prymitywną, czasem wykwintną metaforę. Krew $w$ tych przypadkach wskazuje na biologiczne reakcje organizmu wywołane wpływem drugiej osoby. Przyspieszone tętno, nabiegające krwią policzki, gwałtowność ruchów to tylko kilka z symptomów zdradzających efekt intensyfikacji (...).

Oznaką pożądania, ale i atrakcyjności kobiety mogą być nabrzmiałe krwią usta (...). [Kurkiewicz 2013: 357]

cienie graniczące z ciemnym brązem wchodziły w zakres słowiańskiego pojęcia czerwieni (czerwony = rudy, ryży, ryży + ceglasty, malinowy, wiśniowy itd.)" [Libera 1987: 118]. Kwiryna Handke nie zalicza koloru rudego do pola barwy czerwonej, lecz brązowej [Handke 2002: 231-235]. Alfred Zaręba z kolei traktuje rudy jako barwę czerwoną z odcieniem brązowym [Zaręba 1954: 29]. 
Warto przypomnieć, że za „krwawymi ustami”, „kryją się drapieżne wilcze zęby", co przywołuje motyw kobiety wampirycznej i jest witkiewiczowskim powrotem do mitu o Lilith ${ }^{3}$ [Skwara 2012: 64], pierwszej żonie biblijnego Adama, z którą spłodził chmarę węży. Marta Skwara podkreśla, iż dla obrazu kobiety wampira, metaforycznie żywiącej się krwią umierających u jej stóp mężczyzn, istotny jest opis akwaforty Klingera Die Rivalen, którą znajdziemy w Pożegnaniu jesieni:

3 Nie jest to jedyne nawiązanie do legendarnych bądź mitologicznych postaci kobiecych, do których wracają pisarze modernistyczni, ale również twórcy epok wcześniejszych.Zwraca na nie uwagę oraz charakteryzuje Dominika Spietelun: „Lilith - według niebiblijnych legend, pierwsza żona Adama, pierwsza kontestatorka jego myślenia, stworzona tak, jak i on z prochu i ziemi, skutkiem czego uważała się za równą Adamowi i nie chciała z nim współżyć leżąc pod nim. Nie godziła się na służalczą rolę i porzuciła męża, $w$ akcie buntu dobrowolnie opuściła raj, skazując się na przekleństwo Adama i Boga, przez decyzję stania się oblubienicą Samuela i matką jego dzieci. To pierwsza, która zawarła przymierze z szatanem. Ewa - żona Adama, która powstała z jego żebra, została skuszona przez węża i namówiła Adama do spróbowania zakazanego owocu z Drzewa Poznania Dobra i Zła, co oznaczało złamanie zakazu. (...) Salome - księżniczka żydowska, która oczarowała ojczyma tańcem tak, że ten przyrzekł spełnić każde jej życzenie. Zażądała więc głowy Jana Chrzciciela, którą podano jej na tacy, stała się od tego czasu symbolem niszczącego erotyzmu i mrocznej zmysłowości. Medea - piękna, mściwa czarodziejka, która dla swojego ukochanego poświęciła miłość ojca, możność mieszkania w ojczyźnie. Mimo to została przez niego skrzywdzona, za co zemściła się okrutnie, zabijając ich wspólne dzieci. Penelopa - wierna żona Odysa (...). Helena - symbol kobiecej urody, ale i nieszczęść związanych z wojną trojańską, której stała się bezpośrednią przyczyną. Kleopatra - ostatnia królowa Egiptu, która była kochanką największych władców starożytnego świata rzymskiego, Cezara i Antoniusza, których doprowadziła do zguby. Messalina - rzymska cesarzowa, żona Klaudiusza, słynąca z urody i atrakcyjności nimfomanka, która dopuściła się wielu ekscesów erotycznych i była przyczyną zguby innych. To także Maria Magdalena, Judyta, Dalia, Kirke, Klitajmestra, Isztar, Astarte.

Są to imiona kobiet fatalnych. Tam właśnie tkwi ich początek - w świecie mitycznym i biblijnym (...). Wyliczenie tylko powszechnie znanych postaci czasów najodleglejszych pokazuje bogactwo wizerunku kobiety demonicznej, która skrywa się pod wieloma postaciami. To także nimfa, syrena, harpia, amazonka, bachantka, chimera, hydra, modliszka, meduza, wampir, pająk, pantera, tygrysica, lwica, sęp, sfinks, ptak, wąż, kot, skorpion, jesień czy sama śmierć" [Spietelun 2013: 63-64]. 
(...) dwóch zaciekle dźgających się nożami drabów i „ona” $z$ wachlarzykiem w ręku, obserwująca uważnie, który z nich zuycięży, aby mu się oddać zaraz, na ciepło, zbroczonemu krwią tamtego (PJ 19).

W opisie tym mamy co najmniej trzy pola semantyczne. Pierwsze (...) zakreśla obraz drabów walczących nożami - symbolami męskości. Drugie wyznacza kobieta będąca przyczyną i jednocześnie sędzią pojedynku, ze znakiem ulotnej i dwornej kobiecości $w$ ręku, sprzecznym ze skupionym spojrzeniem kata. Trzecie wreszcie to krew, jednocześnie symbol miłości i seksu, śmierci i odrodzenia, zemsty i opuszczenia" [Skwara 2012, 83].

W dalszej części wskazuje na

instynkt śmierci, na akwaforcie uosabiany przez kobietę wchłaniającą krew. Witkacowski nasycony płcią demon-wampir - pamiętajmy, że w twarzy Heli, oprócz skośnych oczy, najwymowniejsze były krwawe usta (...), usta, jakie widzimy na obrazie pastelowym z roku 1918 zatytułowanym »Kompozycja « - łącząc $w$ sobie objawienie śmierci i seksu, wyjaśnia tajemnicę nieuchronności zgonów kochanków. Atanazy, podobnie jak Bung, umiera, choć pozornie wyzwolił się spod władzy kobiecości, aby żyć mógł demon. Gdy Atanazy »żyć przestał nareszcie«, ta, która wyssała z niego siły życiowe, siedzi na tronie (...). To ona karmi się jego życiem, rosnąc w potęgę i siłę. [Skwara 2012: 83]

Wyróżnić można także nawiązania do drugiego wzorca prototypowego - ognia, odnoszące się do czerwieni, jak i do koloru pokrewnego - purpurowego: „purpurowy poblask” (64), „blado-pomarańczowo-czerwony poblask wieczornej zorzy" (238). Widoczny głównie w opisach zjawisk atmosferycznych i związany z intensywnością refleksów świetlnych zachodzącego lub przysłoniętego chmurami słońca. 
Zdarza się, że oba prototypy nakładają się na siebie: „krwawym blaskiem paliły się ściany szczytów od zachodzącego gdzieś w dolinach słońca” (296), „góry palą się karminowym blaskiem czystego zachodu" (296).

W przykładach, gdy czerwień odwołuje się równocześnie do obu prototypów, światło słoneczne bezpośrednio kojarzy się z ogniem, a związek ten wspomagany jest dodatkowymi określeniami leksykalnymi [Tokarski 2004: 83]: palić się, blask, bezpośrednio nawiązującymi do ognia i płomieni. Związek z krwią podkreślają przymiotniki: „ceglastokrwawy”, „,karminowy”.

Tokarski zaznacza tutaj wyraźną opozycję „wschód - zachód słońca", sprowadzającą się także do ogólniejszej kategorii pojęciowej „,jasny" - „ciemny" [Tokarski 2004: 91]:

Słońce wschodzące zapowiadające nastanie dnia, wiąże się z ogólnie pozytywnym wartościowaniem kategorii »jasny« i »ciepły«. Czerwień aktualizuje wówczas pozytywne konotacje '(odrodzenia się) życia', 'ciepła' jako doznania przyjemnego (...). Wschodzące słońce zdaje się powodować niebezpieczeństwo, pożar (...). Ale analogicznie (...) zachodzące słońce oznacza kres czegoś, kres jasności i dnia, po którym następuje noc. (...) Wyraźnie jednak konotacje barwy czerwony, choć zależne od konkretnej sceny zbliżającej się nocy, motywowane są od prototypu krwi (...). [Tokarski 2004: 91]

Kolor karminowy, podobnie jak purpurowy, wywodzi swoją nazwę

od nazw obiektów z których wytwarzano niegdyś barwniki. Nazwy te przeniesione zostały następnie na odpowiednie określenie kolorystyczne. Wyodrębnia się tutaj kilka kręgów leksykalnych. Są to, po pierwsze nazwy szeroko rozumianych istot żywych, zwłaszcza owadów lub istot niżej rozwiniętych, których bądź z ich wydzielin produkowano barwniki: karmazynowy »(...) 'czerw, robak'«, karminowy 
»z podobną etymologią", purpurowy »wyciąg ze ślimaka rozkolca, dający zabarwienie od intensywnego czerwonego do fioletowego«..." [Tokarski 2004: 146]

Barwa czerwona najczęściej stosowana jest w opisie najbliższego otoczenia Heli i Bertza. Sama willa nazywana jest „Czerwonym Pałacem” (131, 145), którego doskonałą kopią jest dom w Zarytem (dlatego też będą analizowane wspólnie). Bohaterka, wychowana w czerwoności od dzieciństwa, w zupełności podziela gust i zamiłowanie swojego ojca do tego koloru. We wszystkich sprzętach domowych, jak i dekoracjach dominuje barwa czerwona „we wszystkich możliwych odcieniach” (29): „ciemnoczerwone saloniki” (16), „czerwone kafle” (217), „drzwi z czerwonej laki” (140), „czerwona misa”, „czerwone obrazy” (29), „drogocenny kamień w oprawie czerwonych szyb” (32), "schody z czerwonego marmuru” (16), „szafa z czerwonymi lustrami” (32). Tak urządzony dom działa na Atanazego drażniąco, pobudzając do agresji: „Czerwone kolory mebli, obić i dywanów działały nań jak na byka" (16).

Ogólna zasada kolorystyczna dotyczy także strojów Heli Bartz: „różowa piżama” (32), „ceglastoczerwony szlafrok” (68), „najczerwieńszy szlafrok” (29) , „czerwone pantofelki” (262), „czerwone pończochy” (259) oraz ubrań służących: „lokaj w czerwonej liberii” (16), „Józia ubrana była w ciemnobordową sukienkę i cynobrowy fartuszek z takąż koronką" (29).

Kolor cynobrowy ${ }^{4}$, jak pisze Tokarski, jest nazwą pochodną naturalnych związków mineralnych, cynobru - rud rtęci, stanowiących podstawę do wytworzenia barwnika, występujących między innymi w złożach Hiszpanii i Włoszech [Tokarski 2004: 147]. „Substancja barwna rozumiana jest tutaj przede wszystkim jako 'farba, składnik farby, pigment', czyli substancja nadająca barwę” [Madeja 2010: 210]. W kolorze cynobru jest także element dekoracyjny „skomplikowane wieszadełko zrobione z murzyńskich spódniczek

4 W terminologii malarskiej, należy obok sjeny, synopii, czerni, do grupy barw nazywanej „ziemiami” [zob. Tokarski 2004: 168]. 
z Kongo" (241). Z kolei bordowy jest leksemem zapożyczonym z języka francuskiego od nazwy miejscowości słynącej z ciemnoczerwonego wina [Tokarski 2004: 147].

Czerwień nie jest kolorem kojarzonym jedynie z miłością idealizowaną. Związana została prawie nierozerwalnie $z$ „miłością grzeszną". Motyw ten łączony jest często z prostytucją ('czerwone dzielnice' w Amsterdamie, 'okna za czerwonymi firankami'), lecz nie jest on wyraźnie utrwalony w języku [Tokarski 2004: 86]. W powieści zauważamy podobne elementy, mające bezpośredni związek z erotyką: „reszta ciała wyginała w seksualnie obiecujący szkic, cienka, ciemnoczerwona kołdra” (50), jak też „karminowa z byczego surowca szpicruta" (241), która posłuży Heli do bicia kochanka w czasie zbliżenia. Co istotne, bohaterowie rozkoszują się swoim okrucieństwem, co może być interpretowane jako „przejaw walki o dominację i podporządkowanie” [Umińska 2001: 212]. Całość dopina kolorystyka pomieszczeń i ubrań: „czerwony mrok sypialni” (68), „jasnoczerwone, błyszczące ściany łazienki” (30), „karminowe firanki” (36), „piżama purpurowa z deseniem stylizowanych czarnych krzewów hyalisu ze złocistymi owocami” (239), „purpurowa sypialnia” (31).

Pierwszym elementem wyglądu Heli Bartz, jaki ukazuje czytelnikowi Witkacy, są rude włosy bohaterki: „Czyżby szedł teraz, by zdradzić ją, jedyną ukochaną, z niesympatyczną mu w gruncie rzeczy, przeinteligentną Semitką o rudych włosach (...)" (17), określone także jako ryże: „Atanazy zapatrzył się na jej drapieżny profil owiany ryżymi włosami, targającymi się w wichrze" (202) oraz złotorude: „(...) kark łysnął nieprzyzwoicie, lubieżnie, pod gęstwą złotorudych włosów (...)" (121).

Ryszard Tokarski definiuje rudy jako będący koloru rdzy, ciemnobrązowy, natomiast ryży jako żółtopomarańczowy, ceglasty. Oba kolory traktuje synonimicznie, wskazując na ich ograniczony zakres użycia. Rudy dominuje w odniesieniach do włosów ludzkich lub sierści zwierząt, przy czym możliwe są również połączenia, tj. ruda glina czy rude liście. Ryży z kolei występuje wyłącznie w odniesieniu do włosów lub sierści [Tokarski 2004: 170-171]. 
Wśród określeń nawiązujących do zjawisk atmosferycznych dużą część stanowią zjawiska związane z wyładowaniami elektrycznymi, między innymi błyski oraz nawiązania do motywu ognia5: „,zabłysnął rudy płomień włosów” (301), „włosy jej zdawały się płonąć własnym światłem” (301), „ciemnoczerwony żar" (224).

„Rudy płomień włosów” przywołuje skojarzenia z językami ognia, przy czym

płomień to również temperatura sygnalizująca o intensywności i natężeniu wewnętrznych doznań, wraz z którymi pojawia się gorączka ciała i śmierć termiczna.

(...) światło posiada aspekt niszczący, przez co ujawnia swą żywiołowość. Silny blask uniemożliwia oglądanie świata, powoduje, że kontury ulegają dematerializacji, zmysł wzroku, najbardziej wrażliwy na niuanse świetlne, traci zdolność rozpoznawania obiektów, a nawet zdolność ich widzenia. [K. Wilkoszewska i in. 2002: 166-174]

Mniej licznie niż powyższe kolory, w powieści występuje barwa różowa ${ }^{6}$. Pojawia się $w$ opisie przyrody, uwydatniając kolor chmur: „była godzina 8.20 rano (...). Wiotkie, różowe »cirrusy« splątane $w$ fantastyczny welon $w$ zenicie (...) [były] dziwnie nieruchome" (212). Kolor różowy widoczny jest w opisie wschodzącego słońca, zenitu, a połączony z bielą czerwień, akcentuje cechy i odczucia pozytywne [Tokarski 2004: 136].

„Różowy kojarzony bywa często ze spokojną erotyką, pięknem kobiecego ciała" [Tokarski 2004: 136] i prywołuje konotacje z dziewiczością: „Jedna, gwałtownie dysząca, prześliczna pierś

${ }^{5}$ „Ognistość to pierwsza z istotnych cech diabelskości i demoniczności. Przejawia się ona nie tylko $w$ możności ziania nim przez istoty demoniczne, ale również manifestowanie się $w$ ich wyglądzie, por. oczy ogniste, świecace/płomienne/czerwone (= pałające ogniem piekielnym)" [Bartmiński i in. 1996: 300].

6 Jest on semantycznie podporządkowany czerwieni. Achromatyczny składnik bieli pełni funkcje rozjaśniającą i osłabia barwę podstawową [Tokarski 2004: 136]. 
kształtu indyjskiej dagoby, z małą, niewinną jak kwiatek różową brodawką, wąską, w wysokim podbiciu, niebieskawo-biała noga i ręce - to wywalone było na wierzch" (50).

Kolor wiśniowy, którego źródło semantyczne leży u nazwy owocu wiśni, będącego koloru ciemnoczerwonego, zostaje prywołany jako barwa ubrania: „wiśniowy aksamitny szlafrok” (179).

Większość leksemów, które stanowią źródło nazw kolorów, jest bliska użytkownikom języka i bez problemu mogą oni rozpoznać, jaki kolor opisuje dany leksem. Są to przede wszystkim nazwy kolorów, których źródło leży w nazwach owoców (...). [Madeja 2010: 200]

Barwa czerwona jest sygnałem alarmowym, znakiem ostrzegającym przed niebezpieczeństwem, czego funkcję współcześnie pełni „czerwone światło w systemie świateł ulicznych i czerwony kolor w drogowych znakach zakazu" [Tokarski 2004: 81], a w powieści widoczne: „czerwone i zielone sygnały stacji, semafory” (287), „błyskające jedno czerwone światło na ostatnim wagonie” (287).

Oznacza także przynależność do partii komunistycznej: „z czerwoną gwiazdą na piersi po lewej stronie siedział Tempe” (282).

Wśród wszystkich nazw kolorów występujących w Pożegnaniu jesieni Witkiewicza pole semantyczne czerwieni jest najbardziej zróżnicowane pod względem liczby barw niepodstawowych oraz wariantów pochodnych powstałych od formy podstawowej. Składa się ono z 30 leksemów użytych w powieści 85 razy.

Najliczniejszą grupę, podzieloną na cztery kategorie gramatyczne, stanowią przymiotniki - 26 leksemów, użytych w powieści 72 razy, następnie rzeczowniki - 3 leksemy, zastosowane 8 razy, potem czasowniki - 1 leksem, występujący 3 razy oraz przysłówki - 1 leksem, pojawiający się 1 raz.

Największą frekwencją w tekście odznaczają się przymiotniki. Są to takie nazwy, jak: blado-pomarańczowo-czerwony (1), buroczerwony (1), ceglastoczerwony (1), ceglastokrwawy (1), ciemnoróżowy (1), czerwony (31), czerwonobrązowy (1), ciemnobordowy 
(1), ciemnoczerwony (3), cynobrowy (2), czarnoczerwony (1), czarnorudy (1), jaskrawoczerwony (1), jasnorudawy (1), karminowy (3), krwawy (2), najczerwieńszy (1), purpurowy (5), różowy (3), rudawy (2), rudy (6), ryży (1), wiśniowy (1), złotorudy (1), żółtoczerwony (1).

Prawie połowę wszystkich leksemów stanowią przymiotnikowe złożenia słowotwórcze - blado-pomarańczowo-czerwony, buroczerwony, ceglastoczerwony, ceglastokrwawy, ciemnoróżowy, czerwonobrazowy, ciemnobordowy, ciemnoczerwony, czarnoczerwony, czarnorudy, jaskrawoczerwony, jasnorudawy, złotorudy, żóttoczerwony, w których funkcją pierwszego członu jest dokładniejsze scharakteryzowanie odcieniu, „wskazanie na modyfikację tonu, jego jasność czy nasycenie nadrędnej (zwykle) podstawowej nazwy barwy" [Tokarski 2004: 144]. Dzięki użyciu przedrostka naj-, najczerwieńszy, tworzącego stopień najwyższy przymiotników, możemy mówić o rozróżnianiu kolorów ze względu na stopień nasycenia barwą. Czerwony, interpretowany jest jako 'kolor pierwszego pasma tęczy, kolor krwi, zarumieniony' [Szymczak 1978: 337]. Pojawiające się zatem złożenie, tj.: ciemnoczerwony, oparte na dwóch rdzeniach słowotwórczych, możemy interpretować jako 'czerwony w ciemnym odcieniu' [Szymczak 1978: 297].

Drugą grupę pod względem liczebności stanowią rzeczowniki: czerwień (2), czerwoność (3), purpura (2), tzecią czasowniki: czerwienić (się) (3), a do grupy przysłówków należy jeden leksem: czerwono (1).

Przymiotnik rudy, oznaczający 'będący koloru rdzy, ciemnoczerwony, ryży' [Szymczak 1978: 144], występuje w powieści $w$ kontekście koloru włosów bohaterki, nie tylko tych znajdujących się na głowie: „podsuwała mu pod nos (...) rudą nieogoloną pachę" (205) i zdecydowanie wzmacniany odniesieniami do ognia, nawiązuje znaczeniowo do pola czerwieni. Trudno jednak powiedzieć to samo o będących tego koloru zwierzętach: „ruda kotka” (184), „rude sępy i mewy” (276). W tym wypadku barwa ruda zdaje się być bliższa polu semantycznemu brązu. 
Do pola czerwieni należą także przymiotniki: cynobrowy 'mający barwę cynobru' [Szymczak 1978: 322], karminowy 'jaskrawo czerwony' [Szymczak 1978: 889], purpurowy 'ciemnoczerwony z odcieniem fioletowym' [Szymczak 1978: 1080] oraz wiśniowy 'w kolorze wiśni; ciemnoczerwony' [Szymczak 1978: 725], utworzone za pomocą sufiksu -owy, od zeczowników cynober, karmin, purpura, wiśnia. Stanowią odcienie czerwieni o różnym stopniu nasycenia i intensywności - od jasnych, nie stonowanych barw do ciemnych, robiących wrażenie czerni.

Rzeczowniki czerwień i czerwoność, będące pochodnymi przymiotnika, określane jako 'czerwony kolor' [Szymczak 1978: 336], występują wyłącznie jako odzwierciedlenie manii kolorystycznej, określając otoczenie i upodobania bohaterów: „W ogóle czerwoność przeważała w całym pałacu Bertzów: obicie ścian, mebli, dywany, a nawet specjalnie dobierane obrazy miały jako zasadniczy kolor czerwień we wszystkich możliwych odcieniach” (29), „miniaturowy świat mieniący się przepychem wypłowiałej czerwieni" (66), „zdążył się już bowiem zarazić czerwonością domu Bertzów” (178), „łamała czasem rano ogólną zasadę czerwoności” (179), „Willa w górach była (...) kopią stołecznej rezydencji Bartzów: począwszy na czerwoności do słynnej (...) kuchni" (194).

Przysłówek czerwono, pojawiający się w kontekście koloru stroju: "Hela, ubrana czerwono, jak mała dziewczynka” (291), konotuje to samo znaczenie, jakie niesie ze sobą wyraz podstawowy czerwony. Z kolei czasownik czerwienić się - powstały od podstawy przymiotnikowej, w wyniku sufiksacji, informuje o 'procesie stawania się czerwonym, dostawania rumieńców' [Szymczak 1978: 336] i związany jest ze stanami emocjonalnymi. W powieści występuje $w$ kontekście zawstydzonej twarzy Giny, ust Atanazego: "usta czerwieniły mu się jak jakaś rana” (92), a także w odniesieniu do przyrody: „gdzieniegdzie czerwieniała jarzębina" (296).

Porównanie ust mężczyzny do skaleczenia, uszkodzenia ciała wywołuje skojarzenia z krwią. 
Inaczej jest z rzeczownikiem purpura (oznacza to samo, to jego forma pochodna) i przymiotnikiem purpurowy, przywołującym prototyp ognia dzięki zastosowaniu czasownika świecić. Obie formy łą czą się z kategorią zjawisk atmosfery cznych: „Przez zapuszczoną firankę sączył się purpurowy poblask” (64), „zagajniki świeciły szarawą purpurą" (192), „purpurowe jarzębiny świeciły pod słońce jak blaszki" (297) i kategorią rzeczy, pomieszczeń, ubrań (przykłady zostały wymienione wcześniej).

Sama bohaterka powieści, Hela Bertz, jest kobietą niebezpieczną, wysysającą z kochanków siły życiowe. Niemniej przewagę w walce ma mężczyzna, ponieważ reprezentuje wyższe wartości niż kobieta, nawet demoniczna. Sfera biologiczna człowieka stoi $w$ opozycji do sfery metafizycznej. Seks nie poniża kobiet, gdyż to one należą do sfery biologicznej oraz nie mają takich ambicji duchowych jak mężczyźni [Umińska 2001: 211-2012]. Czerwień, wszechobecna w jej stroju i pokojach, może być interpretowana jako odnośnik do sfery erotycznej, pełnej namiętności, ale również zachowań sado-masochisty cznych bohaterów, nawiązujących bezpośrednio do krwi i agresji.

Obrazowanie oparte na prototypie ognia i krwi niesie ze sobą najczęściej odczucie pejoratywne, pejzaże nasycone czerwonością mogą oznaczać nie tylko wschody i zachody słońca, być oznakami jesieni, lecz stanowić odniesienie do rewolucji bolszewickiej i „krwi przelanej”, traktowane także jako zbliżające się zagrożenie, łączone z Witkacowskim katastrofizmem.

\section{Bibliografia}

Estetyka czterech żywiołów - ziemia, woda, ogień, powietrze, Wilkoszewska K. (red.), Universitas, Kraków.

Handke K. [2002], Słownictwo pism Stefana Żeromskiego, t. 5, Universitas, Kraków.

Madeja A. [2010], Skąd pochodza polskie nazwy kolorów, http://sjikp.us.edu.pl/ ps/pdf/ps2010_2_17.pdf. 
Kurkiewicz M. [2013], Tętno epoki: miejsce i rola motywu krwi w literature Młodej Polski, Uniwersytet Kazimierza Wielkiego, Bydgoszcz.

Libera Z. [1987], Semiotyka barw w polskiej kulturze ludowej i w innych kulturach słowiańskich, „Etnografia Polska”, z.1.

Skwara M. [2012], Wśród Witkacoidów. W świecie tekstów, w świecie mitów, Wydawnictwa Uniwersytetu Wrocławskiego, Wrocław.

Słownik języka polskiego, Szymczak M. (red.), t. 1-3, Wydawnictwo Naukowe PWN, Warszawa.

Spietelun D. [2013], Witkacowskie Muzy. Kobiety w egzystencji i dziele artysty, Universitas, Kraków.

Tokarski R. [2004], Semantyka barw we współczesnej polszczyźnie, Wydawnictwo Uniwersytetu Marii Curie-Skłodowskiej, Lublin.

Umińska B. [2001], Postać z cieniem. Portrety Żydówek $w$ polskiej literature, Wydawnictwa Sic!, Warszawa.

Witkiewicz S. I. [2010], Pożegnanie jesieni, Wydawnictwo Zielona Sowa, Kraków. Zaręba A. [1954], Nazwy barw w dialektach i historii języka polskiego, PAN, Wrocław. 